\title{
The 2001 Bethesda System
}

Christine Bergeron, MD. ${ }^{(1)}$

\section{Bergeron C. \\ The 2001 Bethesda System. \\ Salud Publica Mex 2003;45 suppl 3:S340-S344. This paper is available too at: http://www.insp.mx/salud/index.html}

\begin{abstract}
A bstract
The Bethesda system is a system of terminology for reporting the results of cervical cytology. It was developed in 1988, and is now widely used in the United States.This system was updated in April 2001. The most important modifications are the following: a) elimination of the catego ry "satisfactory but limited by", b) the reintegration of benign modifications in the normal category, c) "atypical squamous cells of undetermined significance" is now named "atypical squamous ceIIs" and subdivided into "atypical squamous cells of undetermined significance" and "cannot exclude high grade squamous intraepithelial lesion"; and d) endocervical adenocarcinoma in situ which is now a separate entity. Low grade squamous intraepithelial lesions and high grade squamous intraepithelial cells remain unchanged. Recommendations have been proposed concerning automated review and ancillary testing. This paper is available too at: http://www.insp.mx/salud/index.html
\end{abstract}

Key words: Bethesda System; cytology screening; cervical cancer; human papillomavirus

\section{Bergeron C. \\ El Sistema Bethesda 2001. \\ Salud Publica Mex 2003;45 supl 3:S340-S344. \\ Este artículo también está disponible en: http://www.insp.mx/salud/index.html}

\section{Resumen}

El Sistema Bethesda es un sistema de terminología para informar los resultados de citología cervical. Se inició en 1988 y en la actualidad se usa en todos los Estados Unidos de A mérica. Este sistema se actualizó en abril de 2001. Las modificaciones más importantes son las siguientes: a) eliminación de la categoría "satisfactorio pero limitado por", b) se reintegraron las modificaciones benignas en la categoría normal, c) la categoría "células escamosas atípicas de significado indeterminado" ahora se denomina "células escamosas atípicas", y se subdivide en "células escamosas atípicas de significado indeterminado" y "no se puede excluir una lesión escamosa de alto grado", y d) adenocarcinoma endocervical in situ, que ahora es una entidad separada. Las lesiones escamosas intraepiteliales de bajo y alto grado quedan sin cambios. Se proponen recomendaciones relacionadas con el uso de la revisión automatizada y la utilización de pruebas auxiliares. Este artículo también está disponible en: http:// www.insp.mx/salud/index.html

Palabras clave: Sistema Bethesda; citolo gía; detección o portuna de cáncer; cáncer cervical; virus de papiloma humano
T he Bethesda system was first proposed in $1988^{1}$ as a response model for the interpretation of cervical cell cytology. The aim was to unify the terminology and thereby improve patient management. Following several test years, the system was evaluated in 1991 during a second workshop. ${ }^{2}$ More than $90 \%$ of laboratories currently use this response system in the United States. ${ }^{3}$ The aim of the Bethesda conference which was convened from 30 April to 2 May, 2001, was to re-evaluate the terminology used since 1991, and if neces-

(1) Laboratoire Pasteur Cerba, Cergy Pontoise, Cedex9, France.

Received on: September 17,2002 - Accepted on: January 15, 2003

Address reprint requests to: D octeur Christine Bergeron. Laboratoire Pasteur-Cerba, 95066 C ergy Pontoise C edex 9, France E-mail: bergeron@pasteur-cerba.com 
sary propose new modifications. ${ }^{4}$ Six to ten experts discussed each of the following topics: quality of sampling, benign alterations, endometrial cells, among other topics. A discussion website was used for six months to receive comments regarding recommendations. Each of these groups included a cytopathologist, a cytotechnician, and a clinician among other international experts. The conference convened more than 400 representatives including cytologists, cytotechnicians, pathologists, general physicians, public health physicians and epidemiologists. The conference was organized by the National Cancer Institute (NCI) and sponsored by 44 cytology associations. More than 20 countries were represented.

The recommendations have been presented in the form of a literature review, expert opinions, and commentaries sent through the website over the six months before and after the April 2001 conference. ${ }^{4}$

\section{Specimen adequacy}

Sampling quality was one of the most innovative proposals made in 1988. Three categories were proposed: satisfactory, satisfactory but limited due to unsatisfactory sampling, and unsatisfactory. The second category was used for smears not containing endocervical or metaplastic cells, which are the proof of sampling the transformation area, or partial inflammatory smears. This category was eliminated since clinicians felt obliged to redo the smears. It is now suggested that along with the evaluation of smears, note should be made regarding the presence of less than 10 endocervical cells, inflammation clouding evaluation of more than $75 \%$ of the smear, and that the clinician must make the decision whether or not to redo a new smear.

If the smear is considered inadequate, the reason must be noted. Between 8000 and 12000 squamous cells must be present in a conventional smear, and 5000 cells for a liquid smear. Other reasons for not being able to interpret smears were identical to those presented in 1991. Smears without appropriate patient identification, or those which arrive broken must be considered unsatisfactory. Table I summarizes the Bethesda 2001 system.

\section{General categorization}

This is an optional category which allows for statistical analysis of principal categories: absence of suspected malignant cells, epithelial abnormalities, and others (see below).

\section{Table I \\ The 2001 Bethesda system}

Specimen adequacy

- Satisfactory for evaluation

- Unsatisfactory for evaluation because of (specify reason)

General categorization (optional)

- Negative for intraepithelial lesion or malignancy

- Epithelial cell abnormality

- 0 ther

Interpretation/result

- Negative for intraepithelial lesion or malignancy

- Organisms

Trichomonas vaginalis

Fungal organisms morphologically consistent with Candida species Shift in flora suggestive of bacterial vaginosis

Bacteria morphologically consistent with Actinomyces species

Cellular changes consistent with herpes simplex virus

- 0 ther non-neoplastic findings (Optional to report : list not comprehensive)

Reactive cellular changes associated with

- Inflammation

- Radiation

- Intrauterine contraceptive devise (IUD)

Glandular cells status posthysterectomy

Atrophy

- Epithelial cell abnormalities

Squamous cells

- Atypical squamous cells (ASC)

- of undetermined significance (ASC-US)

- cannot exclude HSIL (ASC-H)

- Low grade squamous intraepithelial lesion (LSIL) encompassing human papillomavirus/mild dysplasia/cervical neoplasia (CIN) 1

- High grade squamous intraepithelial lesion (HSIL) encompassing moderate and severe dysplasia, carcinoma in situ; CIN 2 and CIN 3

- Squamous cell carcinoma

Glandular cell

- Atypical glandular cells (AGC)

- Endocervical

- Endometrial

- Glandular

- Atypical glandular cells, favor neoplastic

- Endocervical adenocarcinoma in situ (AIS)

- Adenocarcinoma: Endocervical endometrial, extrauterine, N OS

- 0 ther (list not comprehensive)

Endometrial cells in a woman $\geq 40$ years of age

Automated review and ancillary testing (Include as appropriate)

Educational notes and suggestions (Optional) 


\section{Interpretation/Results}

\section{A) Negative for intraepithelial lesion or malignancy}

The category "absence of intraepithelial squamous lesion or suspected malignant cell" regroups the categories "normal and benign alterations". The term infection is replaced by microorganisms and the final list has been slightly modified (Table I). Alterations due to inflammation, irradiation, or the presence of an intrauterine contraceptive device (IUD) are classified within normal smears.

\section{B) Epithelial squamous cell abnormalities}

Atypical squamous cells (ASC)

Following numerous discussions, based on the practicality of maintaining or not an invalid category, it has been decided to keep this category which is associated with approximately $10 \%$ of severe intraepithelial neoplasm from biopsies. ${ }^{5,6}$ On the other hand, the subdivisions of this category have been modified (Table I). The general term for this category is no longer "atypical cells of undetermined significance" (ASC-US). It is replaced by the term "atypical squamous cells". The term "atypical squamous cell of undetermined significance" (ASC-US) will be used for abnormalities suggesting a low grade intraepithelial squamous lesion which has not been confirmed, or for non-specific atypical cells. Not more than $3 \%$ of the smears should have this designation. ${ }^{5}$ Atypical findings of undetermined significance associated with inflammation come out of this group and should now be included among normal smears. The term "atypical cellular findings not permitting exclusion of a high grade intraepithelial squamous lesion" (ASC-H) is proposed for those unconfirmed, although suspected cases of high grade intraepithelial squamous lesion. This term should apply to $5-10 \%$ of atypical squamous cell alterations and are often associated with a high grade intraepithelial squamous lesion confirmed through biopsy taken by colposcopy. $^{7-9}$

Squamous intraepithelial lesion

The Bethesda 2001 system has the same two categories as proposed in 1988 which are "low grade intraepithelial squamous lesion" and "high grade intraepithelial squamous lesion" (Table I). Both categories are associated with oncogenic virus or high risk, although they have different natural history. Low gra- de intraepithelial squamous lesions regress spontaneously and evolve slowly to a high grade intraepithelial squamous lesion. High grade intraepithelial lesions are associated with persistent viral infection and with high grade intraepithelial neoplasias detected from biopsy and which can progress to an invasive lesion.

\section{C) Epithelial glandular cells abnormalities}

Atypical glandular cells (AG-C )

The term "atypical endocervical, endometrial or glandular cells" replaces the term "atypical glandular cells of undetermined significance" (AGUS) (Table I). The nature of glandular, endocervical or endometrial cells should be noted; this will permit a more appropriate diagnostic approach, cervical biopsy, and examination of the endocervix to identify endocervical lesion, or endometrial biopsy to identify an endometrial lesion. ${ }^{10}$

Endocervical adenocarcinoma in situ (AIS)

"In situ adenocarcinoma" is a new category which corresponds to specific morphological abnormalities, some have already been using this term for several years. These abnormalities join others which are based on morphological changes from invasive adenocarcinomas of endocervical origin. This category allows for a more aggressive diagnostic approach such as a diagnosis "conization", if the initial diagnostic findings are negative.

\section{Adenocarcinoma}

The category "atypical glandular or endocervical cells suggesting neoplasia" is badly defined on morphological grounds. ${ }^{11-13}$ It should permit early identification of intraepithelial glandular lesions even though it requires prospective studies for confirmation. The category for invasive adenocarcinomas remains identical.

\section{D) Other}

Cervical cytology is not a good diagnostic assay for endometrial cancer. Morphologically benign endometrial cells were not mentioned in the 1988 Bethesda system, except referring to menopausal women. The category "other" is now proposed to classify smears without morphological abnormalities but which have apparently benign endometrial cells, in women over 40 years. The presence of these cells indicates an in- 
creased risk for endometrial cancer, and therefore an endometrial biopsy is recommended. ${ }^{14,15}$ Benign glandular cells found after hysterectomy should be noted as "absence of malignant-like cells".

\section{A utomated review}

The automated system for reading slides should be mentioned in the report and the printout from the machine attached. If the slide was checked by microscopy, this should also be mentioned apart in the report.

\section{Ancillary testing}

It is considered useful to propose recommendations for additional tests which may be complementary to cytology. Suggestions for human papillomavirus DNA (HPV) detection is a primary example of an additional test which can be complementary to cytology.

These recommendations were discussed during a meeting of the North American Society for Colposcopy and Cervical Pathology (ASCCP) between 6-9 Sept. 2001, prior to their acceptance as definitive. ${ }^{16}$

\section{A) Description of methods}

Several methods can be used to detect HPV-DNA. Some of these are type specific, and others use a cocktail of probes which allow detection of oncogenic vs non-oncogenic cell types. Each method has a specificity and sensitivity which depends on the threshold of detection. Detection of low risk or non oncogenic HPV is not essential in the majority of cases.

The report must record the method used and the type of oncogenic HPV tested. If the method uses a cocktail of probes, the result must be described as positive or negative.

\section{B) Clinical indication for management of abnormal smear}

Published data suggest that testing for oncogenic DNA of HPV can be useful for a patient with cytological diagnosis of "atypical squamous cells of undetermined significance".6,16,17 Virology has a higher sensitivity than cytological follow-up to detect the presence of high grade cervical intraepithelial neoplasia (CIN) in this context. On the other hand, virology assay specificity is not as good as cytology. Specificity is the probability that a woman with no intraepithelial neoplasia has a negative viral test. If the prevalence of high grade CIN is $5 \%$ in these patients, the benefit of early detection of a small number of precancerous lesions should be evaluated in light of the cost of unnecessary colposcopy for many patients. ${ }^{18}$ Cost-efficacy studies are required in each country to consider the cost of colposcopy, access to these facilities, cost of monolayer cytology, and cost of virology assays. These types of studies will allow us to evaluate whether virology should be considered for a better case management as compared to cytological follow-up for patients with a cytological diagnosis of "atypical cells of undetermined significance".

According to published data, identification of DNA from a human HPV oncogene is not useful for the majority of patients who have a cytological diagnosis of either low or high grade intraepithelial squamous lesion. ${ }^{17,19}$ However, detection may be useful in certain cases such as for a patient who has persistently negative cytology and negative biopsy for intraepithelial squamous lesion.

There are little data to support the need for identification of an HPV oncogene in patients with cytological diagnosis of "atypical glandular cells".$^{20}$

Other recommendations for identification of an HPV oncogene are being evaluated, although published data are insufficient to propose recommendations. These recommendations would be:

- Primary screening of women older than 35 years.

- Follow up of treated patients to detect persistence or relapse of a lesion.

- Quality control of cytology.

\section{C) Example of reporting}

It is recommended that cytological and virology results should be combined. If the two tests are not conducted in the same laboratory, it is recommended that they refer to each other.

Results can be reported according to several models:

- The "interpretive" model considers both cytology and virology and gives a definitive negative or lesion-oriented diagnosis. Cytological diagnosis of "atypical cells of undetermined significance" (ASC-US) is reinterpreted as a result of the presence or absence of an oncogenic HPV. An example: a cytological diagnosis of ASC-US associated with a negative virology result is considered finally as negative. A cytological diagnosis of ASC-US associated with the presence of an HPV oncogene is considered a low grade intraepithelial lesion.

- The "probabilistic" model gives separate cytological and virology diagnosis, and associated risk 
is suggested in accordance with each case. An example: a notation is included with the report explaining that there is a cytological diagnosis of ASC-US, associated with a positive virology result, which in turn corresponds to $10-20 \%$ risk of having an associated high grade CIN.

- The "additional information" model gives cytological and virology results, and gives a clinical recommendation such as requiring a colposcopy biopsy if cytological diagnosis is ASC-US and virology is positive.

During the Bethesda conference, the audience preferred the probabilistic solution. The group which proposes recommendations has left the choice to each individual laboratory to give results as any one of the three models.

\section{Educational notes and suggestions}

Recommendations for patient management should be clear and concise. They must be given as "suggestions" and in accordance with national and international good clinical practices.

\section{References}

1. N ational Cancer Institute W orkshop.The 1988 Bethesda System for reporting cervical/vaginal cytologic diagnoses. JAMA 1989;262:931-934. 2.The 1991 Bethesda System for reporting cervical/vaginal cytologic diagnoses: Report of the 1991 BethesdaW orkshop. JAMA, 1992;267:1892. 3. D avey DD, N ielsen ML, Rosenstock W, Kline TS.Terminology and specimen adequacy in cervicovaginal cytology:The College of American Pathologists' interlaboratory comparison experience. Arch Pathol Lab Med 1992;116:903-907.

4. Solomon D, Davey D, Kurman R, Moriarty A, 0 Connor D, Prey M et al.Terminology for reporting results of cervical cytology. JAMA 2002, 287, 2114-2119.

5. Davey D, W oodhouse S, Styer P, Stastny J, Mody D. Atypical epithelial cells and specimen adequacy: C urrent laboratory practices of participants in the College of American Pathologist interlaboratory comparison program in cervicovaginal cytology. Arch Pathol Lab Med 2000;124:203-211.
6. Solomon D, Schiffman M,Tarone R. Comparison of three management strategies for patients with atypical squamous cells of undetermined significance: Baseline results from a randomized trial. J N atl Cancer Inst 2001;93:293-299.

7. Q uddus MR, Sung CJ, Steinhoff MM, et al.A typical squamous metaplastic cells: Reproducibility, outcome, and diagnostic features on ThinPrep Pap test. Cancer. 2001;93:16-22.

8. Sherman ME, Tabbara SO, Scott DR et al."ASCUS, rule out HSIL": Cytologic features, histologic correlates and human papillomavirus detection. Mod Pathol.1999;12:335-343.

9. Sherman ME, Solomon D, Schiffman M, for the ALTS Group. $Q$ ualification of ASCUS:A comparison of equivocal LSIL and equivocal HSIL cervical cytology in the ASC US LSIL Triage Study. Am J C lin Pathol.2001;116:386-394.

10. Eddy GL, Stumpf KB,W ojtowycz MA, Piraino PS, Mazur MT. Biopsy findings in five hundred thirty one patients with atypical glandular cells of uncertain significance as defined by the Bethesda System.Am J O bstet Gynecol. 1997;177:1188-1195.

11. Biscotti CV, Gero MA, Toddy SM, Fischler DF, Easley K. Endocervical adenocarcinoma in situ: An analysis of cellular features. Diagn Cytopathol.1997;17:326-332.

12. Lee KR, Manna EA, Jones MA.Comparative cytologic features of adenocarcinoma in situ of the uterine cervix. Acta Cytol. 1991;35:117-126. 13. Soofer S, Sidawy M.Atypical glandular cells of undetermined significance: $\mathrm{Clinically} \mathrm{significant} \mathrm{lesions} \mathrm{and} \mathrm{means} \mathrm{of} \mathrm{patient} \mathrm{follow-up.}$ Cancer. 2000;90:207-214.

14. Montz FJ. Significance of "normal" endometrial cells in cervical cytology from asymptomatic postmenopausal women receiving hormone replacement therapy. Gynecol 0 ncol.2001;81:33-39. 15. N g ABP, Reagan JW, Hawliczek S,W entz BW. Significance of endometrial cells in the detection of endometrial carcinoma and its precursors. Acta Cytol.1974;18:356-361.

16.W right TC Jr, C ox JT, Massad LS, Twiggs LB,W ilkinson EJ, for the 2001 A SC CP-sponsored Consensus Conference. 2001 Consensus guidelines for the management of women with cervical cytological abnormalities JAMA.2002;287:2120-2129.

17. Bergeron $C$, Jeannel $D$, Poveda JD, C assonet $P, O$ rth $G$. Human papillomavirus testing in women with mild cytologic atypia. 0 bstet Gynecol 2000;95:821-827.

18. Harris JE . Correspondence RE. Comparison of three management strategies for patients with atypical squamous cells of undetermined significance : Baseline results from a randomized trial.J $\mathrm{N}$ atl Cancer Inst 2001;93:950-951.

19.The atypical squamous cells of undetermined significance/low-grade squamous intraepithelial lesions triage study (ALTS) group. Human papillomavirus testing for triage of women with cytologic evidence of low-grade squamous intraepithelial lesions: Baseline data from a randomized trial. J N atl C ancer Inst 2000;92:397-402.

20. Ronnett BM, Manos MM, Ransley JE, Fetterman BJ, Kinney W K, Hurley LB et al.A typical glandular cells of undetermined significance: Cytopathologic features, histopathologic results, and human papillomavirus D N A detection. Hum Pathol 1999;30:816-825. 